\title{
AN EXAMINATION OF VOLUNTARY DISCLOSURE, INDEPENDENT BOARD, INDEPENDENT AUDIT COMMITTEE AND INSTITUTIONAL OWNERSHIP: FIRM SIZE AS A MODERATOR
}

\author{
Hisar Pangaribuan \\ Universitas Advent Indonesia - Bandung \\ e-mail: pangabhsr@gmail.com
}

\begin{abstract}
This study examines the impact of the independent board, independent audit committee and institutional ownership on voluntary disclosure (by placing company size as a moderating variable) in Indonesia banking companies. Data collected from the annual report of banking companies listed on the Indonesia Stock Exchange throughout the year of study. Hypotheses developed to be tested with a variance based approach and the results were interpreted. The result has shown that the increase of independent board members and independent audit committee members tend to decrease the level of voluntary disclosure (although the impact is not significant). Independent board and independent audit committee performed this to reduce cost due to a high disclosure and to avoid the threat of high competition in banking companies. The other result has shown that institutional investors are considered more professional and powerful in supervising management to disclose more information to the public. The final section of the study's findings indicated that firm size cannot be as a moderating variable on the impact of the independent board, independent audit committee and institutional ownership toward voluntary disclosure.
\end{abstract}

Keywords: voluntary disclosure, independent board, independent audit committee, institutional ownership, size.

\begin{abstract}
ABSTRAK
Studi ini meneliti dampak dewan independen, komite audit independen dan kepemilikan institusional terhadap pengungkapan sukarela (dengan menempatkan ukuran perusahaan sebagai variabel moderasi) di perusahaan perbankan Indonesia. Data dikumpulkan dari laporan tahunan perusahaan perbankan yang terdaftar di Bursa Efek Indonesia sepanjang tahun studi. Hipotesis dikembangkan untuk diuji dengan pendekatan berbasis varians dan hasilnya ditafsirkan. Hasilnya menunjukkan bahwa peningkatan anggota dewan independen dan anggota komite audit independen cenderung menurunkan tingkat pengungkapan sukarela (walaupun dampaknya tidak signifikan). Dewan independen dan komite audit independen melakukan ini untuk mengurangi biaya karena pengungkapan yang tinggi dan untuk menghindari ancaman persaingan yang tinggi di perusahaan perbankan. Hasil lain menunjukkan bahwa investor institusional dianggap lebih profesional dan kuat dalam mengawasi manajemen untuk mengungkapkan lebih banyak informasi kepada publik. Bagian terakhir dari temuan penelitian menunjukkan bahwa ukuran perusahaan tidak dapat sebagai variabel moderat pada dampak dewan independen, komite audit independen dan kepemilikan institusional terhadap pengungkapan sukarela.
\end{abstract}

Kata Kunci : Pengungkapan Sukarela, Dewan Independen, Komite Audit Independen, Kepemilikan Institusional, Ukuran Perusahan

\section{Introduction}

One of the causes the Asian countries crisis is the low-level implementation of corporate governance. To anticipate the potential of such unwanted circumstances, Indonesia is implementing corporate governance by establishing one committee to manage the implementation of corporate governance and policy (Komite Nasional Kebijakan Tata Kelola Perusahaan - KNKCG) to formulate policy recommendations, initiate and monitor corporate governance improvements (Asian Development Bank, 2000). Transparency is one of the corporate governance pillars. The company increases their transparency by disclosing more information to the public. Disclosure of information 
is essential for banking companies as the main financial institution market and as the heart of economy in the country (Sihombing \& Pangaribuan, 2016).

Banking companies are expected to provide adequate voluntary disclosure to external parties. The voluntary disclosure will provide useful information to investors and creditors in creating more rational investment environment (Belkaoui, 2004). Voluntary disclosure is also considered as a mechanism to reduce information asymmetry between firm and investors (Akhtaruddin \& Haron, 2010; Jiang et al., 2011). Voluntary disclosure reflects the transparency and accountability of management in performing a business operation (Akhtaruddin \& Haron, 2010; Li et al., 2012).

Conflicts arise when managers choose to disclose or not to disclose certain information. Such conflicts usually arise because of unfeasible information that reaches to the public, adequate disclosure will reduce conflicts between owners and managers as the agent (Al-Harun \& Rouf, 2011). Not many companies in Indonesia are announcing their profits by including more detailed voluntary information, most disclosure of information is made on the classification of information that is common and concerns only about the background of the company (Wijantini, 2006). The achievement of voluntary disclosure at manufacturing companies listed on Indonesia Stock Exchange is only at an average of $56 \%$. Based on the assessment of the Organization of Economic Cooperation and Development (OECD) score, the average value of disclosure less than $60 \%$ indicates that the level of voluntary disclosure is at a low position (Utama, 2012).

Some countries in Asia (including Indonesia) have dual board system, where on board there are two levels of supervisor, namely is the board of commissioner as supervisory board and board of director as the executive. In some countries outside of Asia, they use one-tier board system, there is only one executive supervisor that is the board of director (Huang, 2010). In this study the board is a board of commissioner, therefore the independent board is an independent board of commissioner.

Voluntary disclosure of annual reports can be well established if there is an oversight body which is one aspect of corporate governance mechanisms. In the implementation of corporate governance, an instrument that is believed to have an important role in oversight function is the existence of the board (Fama \& Jensen, 1983). IFCASI (2014) states that an independent board is a corporate supervisory organ that has no connection to the company except for supervisory functions. Independent board serves to monitor the financial reporting process and monitoring the transparency implementation through better disclosure of information to ensure the availability of clear and useful information (Forum for Corporate Governance in Indonesia, 2000).

An independent party is required for proper supervision. Based on the regulation set by the financial supervisory body in Indonesia, stated that the independent audit committee is a function that must be established to conduct oversight, the function is a party that has no personal interest in the entity and who work through the responsibility of management, shareholders, business relations or family relationships (Otoritas Jasa Keuangan, POJK No. 55/POJK.04/2015). The Board is authorized to appoint and establish audit committees in assisting supervisory duties (Otoritas Jasa Keuangan, POJK No. 33/POJK.04/2014). The audit committee also serves as a monitor for implementation of information disclosure mechanisms to improve the quality of information flows between owners and managers (Rouf, 2011). The audit committee also serves as a monitor for implementation of information disclosure mechanisms in order to improve the quality of information flows between owners and managers (Rouf, 2011). When there is a high level of independent audit committee member, it will give in a better committee audit commitment so that the supervisory function becomes more optimal (Pangaribuan, 2016). 
Another factor expected to increase voluntary disclosure in an annual report is institutional ownership. Institutional ownership can reduce conflicts of interest between managers and shareholders through reducing opportunistic attitude of managers (Arouri et al., 2014). Institutional ownership has the power by providing incentives to motivate management to disclose quality of financial reports (Mokhtari \& Makerani, 2013).

Another point concern with disclosure is that there is a wide difference of disclosure practice between small companies and the large ones. The large companies tend to make a better voluntary disclosure because they have the good news to deliver to the public (Kaya, 2014). Transparency through information disclosure can increase company's readiness to compete regionally as well a globally. Voluntary disclosure is considered important for research since voluntary disclosure can provide adequate information and is expected to support the achievement of sustainable economic growth.

Based on the description, it is deemed very important to conduct the more indepth study on the impact of the independent board, independent audit committee and institutional ownership on voluntary disclosure in Indonesian banks. This study places firm size as a moderator variable to determine whether the firm size can strengthen or weaken the influence of independent board, independent audit committee and institutional ownership on voluntary disclosure in Indonesian banks.

\section{LITERATURE REVIEW AND HYPOTHESES DEVELOPMENT}

Corporate governance is a system that regulates and controls parties within the company which creates added value for all stakeholders. Corporate governance provides a balance between parties who have authority (Monks \& Minow, 2011). One of the characteristics as a guide to know that corporate governance has been applied properly is the existence of adequate disclosure of information, where information owned by management is relatively balanced when compared with information in the market.

The information disclosed is beneficial for potential investors and creditors in making their investment decisions. Voluntary disclosure is a disclosure that is more than just required (Sanjaya \& Young, 2012). Voluntary disclosure is regarded to fill up the information needed by stakeholders so as to reduce information asymmetries between companies and stakeholders (Jiang et al., 2011). Some companies refuse to perform voluntary disclosure because it is seen that competitors can benefit from information disclosed to the public. Extensive voluntary disclosure of information also seems likely to lead to high cost (Hendriksen \& Breda, 2001; Beattie \& Thomson, 2007).

\section{Independent Board and Voluntary Disclosure}

The implementation of corporate governance regulates the existence of the board to reduce conflict of interest risk between investors and management by conducting supervision in accordance with firm regulations (IFCASI, 2014). The Board is responsible for ensuring the balance of management and shareholder interests, as well as monitoring the implementation of corporate governance through the performing of transparency principles about company information (Forum for Corporate Governance in Indonesia, 2000).

An independent board is a company organ that has no company share, has no affiliation or business relationship with the company and is not the member of the company's management. Indonesia regulation stipulates that the number of board members must consist of at least two members and the composition of independent board members of an enterprise at least $30 \%$ of the total number of existing members (Otoritas Jasa Keuangan, POJK No. 33/POJK.04/2014). The independent member does not come from a consulting agency or public accounting firm that serves the company (IFCASI, 2014). 
Independent board functions to monitor and control the actions of directors for their opportunistic behavior (Jensen \& Meckling, 1976). There is a significant positive correlation between the proportions of independent board members with voluntary disclosure (Chakroun, 2013). Another study suggests that independent boards affect voluntary disclosure (Nandi \& Gosh, 2012). Another study conducted to investigate the impact of board proportion on voluntary disclosure found that the proportion of independent board members had no significant impact on voluntary disclosure (Aboagye et al., 2012; Habbash et al., 2016).

\section{Independent Audit Committee and Voluntary Disclosure}

Sarbanes-Oxley obliged public companies to form an independent audit committee. Furthermore, the Indonesian financial inspection body stipulates that the audit committee should be established by the board. The committee is in charge of assisting the board in conducting control. It is further stipulated that the number of audit committee members in the firm shall consist of at least three persons and $30 \%$ of its members must be independent members (Otoritas Jasa Keuangan, POJK No. 55/POJK.04/2015). The audit committee is in charge to oversee the financial reporting process, establishing communication with external auditors, and ensuring that shareholders and creditors are able to receive financial information (Braiotta et al., 2010).

Independent audit committee members are believed can perform better in their oversight tasks, including in reviewing the information released by management. The members undertake supervision to reduce the occurrence of errors and irregularities in financial statements (Rouf, 2011). The previous study has found that the presence of independent audit committee has a significant impact on voluntary disclosure (Madi et al., 2014; Gantyowati \& Nugraheni, 2014). Another study has found that independent audit committee has a positive relationship with voluntary disclosure (Rouf, 2011). Based on research conducted by Al-Janadi et al., (2013) there was no significant relationship between the proportions of the independent audit committee with voluntary disclosure. In another study, it was mentioned that an increase in the members of the independent audit committee does not mean that the more experienced audit committee members become increased as well (Adhikary \& Mitra, 2016).

\section{Institutional Ownership and Voluntary Disclosure}

Entities or individuals who have shares of a certain company will have voting rights to take part in corporate decision making so that ownership structures can affect how the company operates. Institutional ownership is the percentage of shares owned by an institution divided by the number of outstanding shares (Mokhtari \& Makerani, 2013). Institutional investors are the good corporate overseers, they are professional investors and experts in evaluating the company's financial performance and financial information (Crane et al., 2016). The presence of an institution in share ownership can monitor and limit the behavior of managers, influence the process of preparing financial statements and encourage management to present voluntary disclosures (Cornett et al., 2006).

Institutional ownership is regarded as one of the most effective corporate governance mechanisms. Institutions usually have a large percentage of shares in a particular company, so that through the ownership of such shares will provide a strong power to monitor disclosure practices (Al-Harun \& Rouf, 2011). Such great power can provide control over opportunistic behavior and profit manipulation performed by management (Mokhtari \& Makerani, 2013). Institutional investors have a better access to professionals within the company, the circumstance provides distinct advantages to monitor and control corporate policies (Crane et al., 2016). Several studies have revealed 
that there is a significant positive correlation between the percentage of institutional ownership and voluntary disclosure (Dulacha, 2007, Al-Harun \& Rouf, 2011; Kangarlouei et al., 2013; Audra \& White, 2015), while Azzam, (2010) said that concentrated institutional ownership has no significant impact on information disclosure and stock return.

\section{Firm Size as a Moderator Variable}

The large companies have good resources to collect data, to analyze data and to oversee the board in managing the presentation of better financial statements. The Large companies also have professional human resources in improving company performance (Botosan, 1997). The larger companies are often becoming the focus of society and government on wealth redistribution, taxes and institutional actions (Scaltrito, 2016). In this study, firm size is measured from the total assets of the company at the end of the accounting period (Alfraih \& Almutawa, 2017).

Company size is also often related to the company's ability to disclose information. The large companies tend to disclose more information because the company's ability can bear a high cost, while the small ones think that voluntary disclosure can threaten themselves in their competition (Scaltrito, 2016). Large companies tend to provide incentives for corporate managers to disclose more information than small companies (Karim et al., 2013). Firm size can moderate so that disclosure can be strengthened or weakened in the research model, the bigger the company the greater disclosure (Kaya, 2014).

Based on the above theoretical descriptions, this study builds the following research hypotheses:

$\mathrm{H}_{1}$ : The proportion of independent board member has a significant impact on voluntary disclosure.

$\mathrm{H}_{2}$ : The proportion of independent audit committee member has a significant impact on voluntary disclosure.

$\mathrm{H}_{3}$ : The institutional ownership has a significant impact on voluntary disclosure.

$\mathrm{H}_{4}$ : Company size can moderate the impact of the proportion of independent board member on voluntary disclosure.

$\mathrm{H}_{5}$ : Company size can moderate the impact of the proportion of independent audit committee member on voluntary disclosure.

$\mathrm{H}_{6}$ : Company size can moderate the impact of institutional ownership on voluntary disclosure.

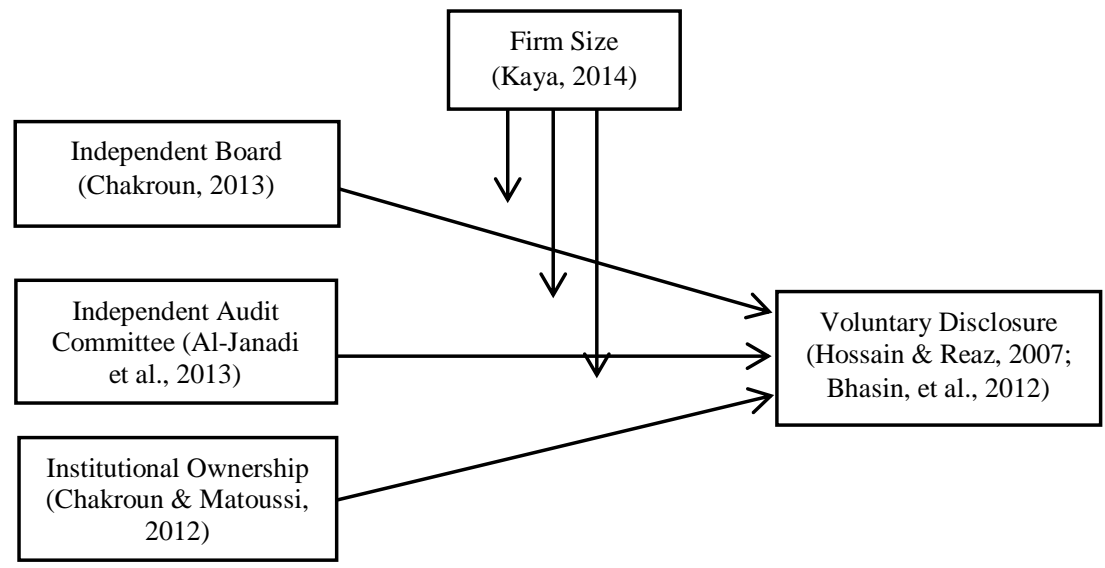

Figure 1. Research framework 
The research framework in Figure 1 provides an overview of the research model built. This study places independent board, independent audit committee and institutional ownership as exogenous variables, a further voluntary disclosure is placed as an endogenous variable and firm size as a moderating variable in the model.

\section{Methodology}

This is an explanatory confirmatory study, hypotheses developed and tested aims to determine the direct impact of exogenous variables on endogenous variable conform to the research model built. The study also aims to examine the moderation effects of firm size on voluntary disclosure. The data used are secondary data namely from the banks' annual report, the data obtained from the website of Indonesia Stock Exchange for banking companies throughout the year of 2014-2016. There are 43 banks listed on January 2017, it is also found that there are 4 new banks listing between January 1, 2014, and December 2016, thus the sample in this study are 39 banks representing all banking company in Indonesia, for 3 years of observation data, thus there are 117 sample data to be observed and processed. Hypotheses testing for direct and moderation effect is performed with a variance based approach using smart PLS.

Independent board is measured by the proportion of independent board members in the bank that is from the number of independent board members divided by the total board members (Chakroun, 2013). Independent audit committee is measured by the proportion of existing independent audit committee members that are from the total number of independent audit committee members divided by the total members of the audit committee (Al-Janadi et al., 2013). Institutional ownership is measured by the percentage of shares held by the institution that is the number of shares held by the institution divided by the total amount of outstanding shares (Chakroun \& Matoussi, 2012). Firm size is measured by the total assets of the firm in each observation period (Kaya, 2014). To avoid the big difference range of numbers between the variable of the firm size with other variables in the study, before hypothesis testing is done, total assets in this research must first be converted with natural logarithm.

The calculation of voluntary disclosure scores is performed with content analysis approach that is by giving a score of 1 if the item disclosed and a score of 0 if the item is not disclosed by the company. Furthermore, the total items disclosed by the company is divided by the maximum total of all disclosure items. Voluntary disclosure items were adopted from previous research (Hossain \& Reaz, 2007; Bhasin, et al., 2012) which has been adapted with the disclosure regulation in Indonesia, so there are 48 items of disclosure used in this study. The voluntary disclosure variable consists of 8 classifications namely general corporate information, corporate strategy information, corporate governance information, financial performance information, risk management information, key non-financial information, corporate social disclosure and other information.

\section{Result}

There are 43 banks listed on the Indonesia Stock Exchange, four of which are listed the issuance of shares after January 1, 2014, so that 39 banks became the research samples during the 3-year, in total, there are 117 research observation data. 


\section{Descriptive Statistic}

Table 1 provides the research variable description data presented to determine the mean, minimum, maximum and standard deviation of research data. The average value of independent board members is 59\%. The lowest and highest values of independent board proportions are $40 \%$ and $100 \%$, respectively. These findings indicate that all banking companies in Indonesia have met the regulatory requirements of the Financial Services Authority, No. 33/POJK.04 / 2014 which requires 30\% of independent board members of the total board members.

Table 1. Statistic descriptive

\begin{tabular}{lcccc}
\hline & Mean & Minimum & Maximum & Stdrd Deviation \\
\hline Independent Board & 0.59 & 0.40 & 1.00 & 0.10 \\
Independent Audit Committee & 0.95 & 0.50 & 1.00 & 0.11 \\
Institutional Ownership & 0.63 & 0.00 & 1.00 & 0.31 \\
Firm Size (in IDR million) & $124,196,692$ & $1,641,451$ & $1,038,706,009$ & $226,714,741$ \\
Voluntary Disclosure & 0.67 & 0.38 & 0.85 & 0.10 \\
\hline
\end{tabular}

It was also found that the average value of independent audit committee members was $95 \%$. The minimum value of the proportion of independent audit committee members was $50 \%$, while the maximum value was $100 \%$. These findings indicate that all banking companies in Indonesia have met the requirements of the Financial Services Authority regulation, POJK no. 55/POJK.04 / 2015 which requires that members of the independent audit committee have a minimum of $30 \%$ of the total members of the audit committee.

Table 1 also shows that the average value of institutional ownership was 63\%, with a minimum value of $0 \%$ which means that there are no banking companies that do not have institutional investors. The data also shows that there is a bank that is $100 \%$ owned by the institution. Improved institutional ownership is believed to improve supervision for the better, reduce conflicts of interest between owners and agents (Arouri et al., 2014), so as to improve the quality of information disclosure (Mokhtari \& Makerani, 2013). In the same table, it is also found that the average firm size value proxied by the total asset (in millions) is $\mathrm{Rp} 124,196,692$, the minimum value of $\mathrm{Rp}$ $1,641,451$ and the maximum value is $\mathrm{Rp} 1,038,706,009$. The standard deviation value of firm size is Rp 226,714,740,560,869 greater than the mean value which means high data spreading occurs.

It was also found that the average voluntary disclosure score was $67 \%$, with a minimum value of $38 \%$ and a maximum value of $85 \%$. High voluntary disclosure of information demonstrates the fulfillment of management commitment to the delivery of publicly available information so that it is expected to improve management's confidence in making investment decisions. It should also be noted that the overall data on the variables of this research (except for firm size variables) has a fairly good spreading/distribution of data, proving that the standard deviation value has a value smaller than the mean.

There is a tendency that banking companies in Indonesia only reveal general informatio. Beattie \& Thomson, (2007) and Gregory et al. (2004) argue that efforts to disclose specific information are perceived to pose a threat to business market competition and contain high costs, while companies may not obtain direct benefits from such disclosures. On the basis of cost and potential threats to the company, it is likely that fewer banking companies disclose information about financial performance, corporate governance information and risk management information. 


\section{Hypotheses Testing}

Table 2. Overview result

\begin{tabular}{lcccc}
\hline & AVE & $\begin{array}{c}\text { Composite } \\
\text { Reliability }\end{array}$ & $\begin{array}{c}\text { Cronbachs } \\
\text { Alpha }\end{array}$ & R Square \\
\hline Independent Board & 1,00 & 1,00 & 1,00 & \\
Independent Audit Committee & 1,00 & 1,00 & 1,00 & \\
Institutional Ownership & 1,00 & 1,00 & 1,00 & \\
Firm Size & 1,00 & 1,00 & 1,00 & \\
Voluntary Disclosure & 1,00 & 1,00 & 1,00 & 0,461 \\
\hline
\end{tabular}

Table 2 shows that the reflective indicators of independent board proportions, the proportion of independent audit committees, institutional ownership, firm size (proxied by total asset value) and voluntary disclosure have met the loading factor requirement of $>$ 0.7, AVE and Cronbach's alpha> 0.5 values means that the model is worthy of further processing for hypothesis testing. The result of the coefficient of determination $\left(\mathrm{R}^{2}\right)$ shows that the proportion of independent board members, the proportion of independent audit committee, institutional ownership, and firm size contributes $46.1 \%$ to voluntary disclosure, the remaining $53.9 \%$ is determined by other variables outside this study. Other variables that can determine high voluntary disclosure may be management commitment and effectiveness of corporate governance implementation.

This research is conducted at the level of $\alpha=5 \%$, based on the rule of thumb inner test model, then the results are significant if t-count $>1.96$. The research model is path analysis, there are 6 hypotheses developed to be tested with variance based analysis approach (using smart PLS). The results of testing the direct effects between variables can be found in Figure 2.

The results of independent board testing of voluntary disclosure found that $t$ statistics are valued at 0.138 which means that independent board has no significant impact on voluntary disclosure. The value of the path coefficient of -0.011 indicates that increasing independent board members can decrease the level of voluntary disclosure. Existing boards lack in motivating management to make high voluntary disclosures with high disclosure considerations may pose a threat to business competition and may increase disclosure costs. The test results show that $\mathrm{H} 1$ is rejected, the independent board has no significant impact on the increase of voluntary disclosure. These findings are in line with previous studies which state that the board has no significant impact on voluntary disclosure (Aboagye et al., 2012; Habbash et al., 2016). However, the results of this study are not in line with previous studies which show that independent audit committees have a significant impact on voluntary disclosure (Nandi \& Gosh, 2012; Chakroun, 2013). 


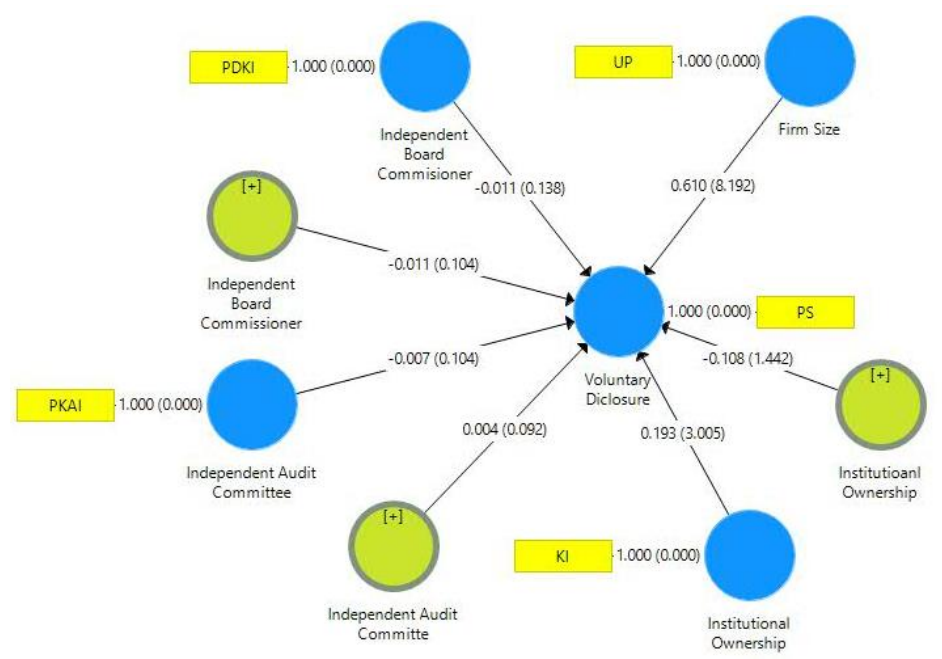

Figure 2. Full diagram

The relationship between the independent audit committee and voluntary disclosure found that the path coefficient is negative, with a value of -0.007 with t count 0.104 then $\mathrm{H} 2$ rejected. Negative values on the path coefficient indicate that an increase in the independent audit committee may decrease the level of voluntary disclosure. In line with the direction of the independent board on the findings above, the increase in the number of independent audit committee members does not tend to increase voluntary disclosure, due to the consideration that disclosure of high information can contain high costs and can increase competition opportunities. At count less than 1.96 indicates that an independent audit committee board has no significant impact on voluntary disclosure. The results of this study are in line with previous research which states that the independent audit committee has no significant impact on voluntary disclosure (Bedard \& Gendron, 2010), but this study contradicts the results of other studies (Rouf, 2011; Madi et al., 2014; Gantyowati \& Nugraheni, 2014).

Institutional ownership has a significant impact on voluntary disclosure with a path coefficient of 0.193 and t count of 3.005, then H3 is accepted. A positive-value coefficient indicates that institutional ownership is alongside the direction of movement of the increase of voluntary disclosure. The results of this study are in line with previous research which states that the higher the percentage of shares held by institutional shareholders, the higher the level of voluntary disclosure. The institutional shareholders are professional investors and have strong influence so as to be more capable in directing management to perform higher voluntary disclosures (Al-Harun \& Rouf, 2011; Kangarlouei et al., 2013; Audra \& White, 2015). The results of this study are inconsistent with findings which state that institutional ownership has no significant impact on voluntary disclosure (Azzam, 2010).

The first moderator test results show that the path coefficient value is -0.011 and the statistic $t$ value is $0.104(0.104<1.96)$ which means that the firm size variable cannot moderate the influence of the proportion of independent boards toward voluntary disclosure, which indicates that $\mathrm{H} 4$ is rejected. The second calculation result indicates that the coefficient path value of 0.004 and the statistic $t$ value of $0.092(0.092<1.96)$ means that the firm size variable cannot moderate the influence of the proportion of the independent audit committee on voluntary disclosure, indicating that $\mathrm{H} 5$ is rejected. The result of the third calculation test found that the value of path coefficient is -0.108 and $t$ statistic is $1,442(1,442<1,96)$, which means that firm size variable cannot moderate the influence of institutional ownership on voluntary disclosure, which indicates that H6 is 
rejected. This study shows that firm size is not determinant in strengthening or weakening the determination of voluntary disclosure in banking companies in Indonesia.

\section{Conclusion}

This study has shown that independent board and independent audit committees have no significant impact on voluntary disclosure. This is because independent board members and independent audit committee members who are right-handers of the board assume that voluntary disclosure can benefit competitors and pose a high level of competition. Independent boards and independent audit committees also pay attention to the costs incurred by management efforts to disclose voluntary disclosures. Such considerations may encourage them to suggest that management not make high voluntary disclosures given the risk of misuse of disclosed information and costs incurred. This indicates that there is still a need for better oversight of independent boards and independent audit committees in an effort to increase public disclosure to stimulate the stock market and investor protection in Indonesia's stock market, particularly in the banking industry.

The study also found that the higher the percentage of shares held by institutions in a banking company, the higher the level of voluntary disclosure by management with a significant level of influence. Institutional investors can monitor, limit and influence the behavior of managers to disclose more information to the public so that institutional ownership can significantly influence voluntary disclosure. This study also proved that firm size can not strengthen or weaken the influence of independent board, independent audit committee and institutional ownership on voluntary disclosure. Further studies are required to find moderating variables (eg culture or belief) and variables that can influence voluntary disclosure in banking companies in Indonesia because good disclosure leads to transparency that benefits the various parties.

\section{REFERENCE}

Aboagye, O. F., Bedi, I. \& Kwakye, T. O. (2012). Corporate governance and disclosure practice of Ghanaian listed companies, Journal of Accounting in Emerging Economies, 2(2). .

Adhikary, B. K. \& Mitra, R. K. (2016). Determinants of audit committee independence in the financial sector of Bangladesh. Applied Finance and Accounting, 2(2): 46-56, August.

Akhtaruddin, M. \& Haron, H. (2010). Board ownership, audit committees' effectiveness, and corporate voluntary disclosures. Asian Review of Accounting, 18(3): 245-259.

Alfraih, M. M., \& Almutawa, A. M. (2017). Voluntary disclosure and corporate governance: empirical evidence from Kuwait. International Journal of Law and Management, 59(2):217-236.

Al-Harun, M. A. \& Rouf, M. A. (2011). Ownership structure and voluntary disclosure in annual reports of Bangladesh. Pak. J. Commer. Soc. Sci, 5(1), 129-139.

Al-Janadi, Y., Rahman, R. A. \& Omar, N. H. (2013). Corporate governance mechanism and voluntary disclosure in Saudi Arabia. Research Journal of Finance and Accounting, 4(4): 25-36.

Arouri, H., Hossain, M., and Muttakin, M. B. (2014). Effects of board and Ownership structure on corporate performance: Evidence from GCC countries. Journal of Accounting in Emerging Economies, 4(1):117-130. 
Asian Development Bank. (2000). Corporate governance and finance in East Asia, $1^{\text {st }}$ vol. Asian Development Bank, Manilla.

Audra, B. dan White, J. (2015). The effect of institutional of ownership on firm transparency and information production. Journal of Financial Economics.

Azzam, I. (2010). The impact of institutional ownership and dividend policy on stock returns and volatility: evidence from Egypt. International Journal Of Business, 15(4), 2010 Issn: 1083-4346. Department of Management, American University in Cairo AUC Avenue, Cairo, Egypt.

Beattie, V. \& Thomson, S. J. (2007). Lifting the lid on the use of content analysis to investigate intellectual capital disclosure. Accounting Forum, 31: 129-163.

Bedard, J., \& Gendron, Y. (2010). Strengthening the financial reporting system: can audit committees deliver?. International Journal of Auditing, 14(2), 174-210.

Belkaoui, A. R. (2004). Accounting Theory. $5^{\text {th }}$ edition. Thomson Learning.

Bhasin, M. L., Makarov, R. R. \& Orazalin, N. S. (2012). Determinants of voluntary disclosure in the banking sector: An empirical study. International Journal of Contemporary Business Studies. 3(3): 2156:7506.

Botosan, C. A. (1997). Disclosure level and the cost of equity capital. The Accounting Review, 72(3):323-349. July.

Braiotta, L., Gazzaway, R. T., Colson, R. \& Ramamoorti, S. (2010). The Audit Committee Handbook. Canada: John Wiley \& Sons, Inc.

Chakroun, R. (2013). Family control, board of directors' independence and extent of voluntary disclosure in the annual reports: case of Tunisian companies. Journal of Business Studies Quarterly, 5(1).

Chakroun, R. \& Matoussi, H. (2012). Determinants of the extent of voluntary disclosure in the annual reports of the Tunisian firms. Accounting and Management Information Systems, 11(3) : 335-370.

Cornett, M. M., Marcus, A. J., Saunders, A. S. \& Tehranian, H. T. (2006). Earning management, corporate governance, and true financial performance. Available at SSRN: https://ssrn.com/abstract=886142., [9 March 2018].

Crane, A. D., Michenaud, S., \& Weston, J. P. (2016). The effect of institutional ownership on payout policy: evidence from index thresholds. The Review of Financial Studies, 29(6).

Dulacha, G. B. (2007). Determinants of voluntary disclosure in Kenyan companies annual reports. African Journal of Business Management, 1(5): 113-128.

Fama, E. F. \& Jensen, M. C. (1983). Separation of ownership and control. Journal of Law and Economics, 26(2): 301:325.

Forum for Corporate Governance in Indonesia (2000). Seri tata kelola perusahaan.

Gantyowati, E. \& Nugraheni, R. L. (2014). The impact of financial distress status and coporate governance structures on the level of voluntary disclosure within annual reports of firms. (Case study non-financial firms in Indonesia over the period 2009-2011). Journal of Modern Accounting and Auditing. 10(4) : 389-403. April 2014.

Gregory, M.F., Bosch, F.A.J.V., \& Henk, V. (2004). The importance of disclosure in corporate governance self-regulation across Europe: a review of the winter report and the EU action plan. International Journal of Disclosure and Governance. March 2004; Vol. 1, No.2.

Habbash, M., Hussainey, K., \& Awad, A. E. (2016). The determinants of voluntary disclosure in Saudi Arabia: an empirical study. International Journal Auditing and Performance Evaluation. 12(3): 213-236. 
Hendriksen, E. S. \& Breda, M. F. V. (2001). Accounting Theory, $5^{\text {th }}$ Ed. Boston: Southern Methodist University.

Hossain, M. \& Reaz, M. (2007). The determinants and characteristics of voluntary disclosure by Indian banking companies. Corporate Social Responsibility and Environmental Management, 14: 274-288.

Huang, C. J. (2010). Board, ownership and performance of banks with a dual board system: evidence from Taiwan. Journal of Management and Organization, Vol. 16.

IFCASI - International Financial Corporation Advisory Service in Indonesia. (2014). The Indonesia corporate governance manual. Jakarta: OJK dan IFC.

Jensen, M. C. \& Meckling, W. H. (1976). Theory of the firm: managerial behavior, agency costs and ownership structure. Journal of Financial Economics, 3:303360.

Jiang, H., Habib, A. \& Hu, B. (2011). Ownership concentration, voluntary disclosures and information asymmetry in New Zealand. The British Accounting Review, 43(1):39-53.

Kangarlouei, S. J., Birjandi, H. A. \& Motavassel, M. (2013). The effect of ownership structure on voluntary disclosure in Tehran Stock Exchange. International Journal of Business Analytics and Intelligence. 1(1): 22-31.

Karim, K. E., Pinsker, R., \& Robin, A. (2013). Firm size and the voluntary disclosure of nonfinancial information by private versus public firm managers. Managerial Auditing Journal, 28(9):866-892.

Kaya, D. (2014). The influence of firm-specific characteristics on the extent of voluntary disclosure in XBRL: Empirical analysis of SEC filings. International Journal of Accounting and Information Management, 22(1): 2-17.

Li, J., Mangena, M. \& Pike, R. (2012). The effect of audit committee characteristics on intellectual capital disclosure. The British Accounting Review, 44(2):98-110.

Madi, H. K., Ishak, Z. \& Manaf, N. A. (2014). The impact of audit committee characteristics on corporate voluntary disclosure. International Conference on Accounting Studies. ICAS 2014.

Mokhtari, Z. \& Makerani, K. F. (2013). Relationship of institutional ownership with firm value and earning quality: Evidance from Tehran Atock Exchange. International Journal of Economy. 2(7):495-502. July.

Monks, R. A. G. \& Minow, N. (2011) Corporate Governance 5th edition. United Kingdom: John Wiley \& Son Ltd.

Nandi, S. \& Ghosh, S. (2012). Corporate governance attributes, firm characteristics and the level of corporate disclosure: Evidence from the Indian listed firms. Decision Science Letters, 2:45-58.

Pangaribuan, H. (2016). Pengaruh Karakteristik Komite Audit, Karakteristik Dewan Komisaris dan Struktur Kepemilikan terhadap Kualitas Audit serta Implikasinya terhadap Kinerja Keuangan Perusahaan. Disertasi doktoral. Universitas Katolik Parahyangan, Bandung.

Otoritas Jasa Keuangan. (2014). Peraturan Otoritas Jasa Keuangan Nomor 33/POJK.04/2014 tentang direksi dan dewan komisaris emitem atau perusahaan publik. Jakarta: Otoritas Jasa Keuangan.

(2015). Peraturan Otoritas Jasa Keuangan Nomor 55/POJK.04/2015 tentang Pembentukan dan Pedoman Pelaksanaan Kerja Komite Audit. Jakarta: Otoritas Jasa Keuangan. 
Rouf. A. (2011). Corporate characteristics, governance attributes and the extent of voluntary disclosure in Bangladesh. African Journal of Business Management. 5 (19): 7836-7845. 9 September 2011.

Sanjaya, I.P.S., \& Young, L. (2012). Voluntary disclosure and earnings management at bank companies listed in Indonesia Stock Exchange. China-USA Business Review. ISSN 1537-1514. March 2012, Vol. 11, No. 3.

Scaltrito, D. (2016). Voluntary disclosure in Italy: Firm-specific determinants an empirical analysis of Italian listed companies. EuroMed Journal of Business, 11(2): 272-303.

Sihombing, J., \& Pangaribuan, H. (2016). Corporate governance structure, disclosure and information asymmetry in Indonesia banking industry. Journal of International Scholars' Conference. Vol 1, No 3 (2016)

Utama, A. A. (2012). Company disclosure in Indonesia: Corporate governance practice, ownership structure, competition and total assets. Asian Journal of Business and Accounting, 5(1):75-108.

Wijantini. (2006). Voluntary disclosure in the annual Reports of financially distressed Companies in Indonesia. Gadjah Mada International Journal of Business. September-December 2006, Vol. 8, No. 3, pp. 343-365. 